\title{
Factors Associated with 0-28 Day Neonatal Mortality in Central Aceh Regency
}

\author{
Asriwati Amirah ${ }^{1}$, Thomson P Nadapdap ${ }^{1}$, Suryani $^{2}$ \\ ${ }^{1}$ Faculty of Public Health, Helvetia Institute of Health Medan, Indonesia \\ ${ }^{2}$ Student of Master Program in Public Health, Helvetia Institute of Health, Indonesia
}

\begin{abstract}
This study aims to determine the factors associated with neonatal mortality 0-28 days in Central Aceh District in 2020. This research is a quantitative study with a case control research design and uses a retrospective approach. The study population was all mothers giving birth whose babies died at the age of 0-28 days from January to December 2020. The sample in this study was 120 respondents consisting of 60 cases and 60 controls. The sampling technique used was total sampling. Data analysis using chi square test and multiple logistic regression test. The results of the bivariate analysis using the chi square test showed that there were 2 variables that were significantly related to neonatal mortality, namely the maternal age variable with $\mathrm{p}$ value $=0.012$ and the pregnancy examination variable with $\mathrm{p}$ value $=0.047$. The results of multivariate analysis with multiple logistic regression test showed that there were 3 variables that influenced neonatal mortality, namely the maternal age variable with a $\mathrm{p}$ value of 0.001 , the birth spacing variable with a $p$ value of 0.018 and the pregnancy examination variable with a $\mathrm{p}$ value of 0.018 , while the most dominant variable affecting the incidence of death Neonatal age is the variable of maternal age with an OR value of 4.397.
\end{abstract}

Keywords: Neonatal Death, Case Control

Received : October 17, 2021

Received in Revised: November 12, 2021

Accepted: November 28, 2021

\section{Introduction}

Health development is an inseparable part of national development. The improvement in health status that the government continues to strive for is influenced by several factors, including the environment, behavior and medical services. These factors ultimately also affect the survival of children, which is reflected by one of the indicators of the impact of health development, namely the infant mortality rate (Kemenkes RI, 2015). The health status of a country can be seen from the main health indicators, such as the Infant Mortality Rate (IMR) and Maternal Mortality Rate (MMR) (Kemenkes RI, 2019). Various reports show that neonatal mortality occupies the highest proportion of deaths that occur in infants in the world. The results of research in various countries show that the factors associated with neonatal mortality are maternal age (Prabamurti, et al., 2008), maternal nutritional status and gestational age (Ima Azizah, 2017), birth spacing (Mekonnen, et al., 2013), parity (Singh et al., 2013), delivery complications (Singh et al., 2013) and delivery facilities (Tura et al., 2013). Research conducted (Yani and Duarsa, 2013) found that antenatal care and birth attendant had a relationship with.

\section{Methods}

This research is a quantitative study with a case control research design and uses a retrospective approach. The population in this study were all mothers who gave birth and their babies died aged 0-28 days from January to December 2020 as many as 64, and mothers whose babies

Copyright $@$ ( 2021, International Journal Papier Advance and Scientific Review, Under the license CC BY-SA 4.0

DOI: $\underline{\text { https://doi.org/10.47667/ijpasr.v2i2.123 }}$ 
lived more than 28 days from January to December 2020 as many as 3,918. The sampling technique in this study was carried out with total sampling, namely the entire population was sampled.

\section{Results and Discussion}

\section{Univariate Analysis}

\section{Mother Age}

The results of the univariate analysis for the maternal age variable can be seen in the following table:

Table 1. Distribution of Frequency by Age of Mother in Central Aceh Regency in 2020

\begin{tabular}{|l|c|c|}
\hline Mother's Age & $\mathrm{n}$ & $\%$ \\
\hline 1. Risk & 40 & 33,3 \\
2. Not at risk & 80 & 66,7 \\
\hline Sum & 120 & 100 \\
\hline
\end{tabular}

Table 1. shows that of the 120 respondents studied, respondents who have a risky age of $<20$ years or $>35$ years are 40 respondents $(33.3 \%)$, and those who are not at risk (20-35 years) are 80 respondents $(78,3 \%)$.

\section{Parity}

Table 2. Frequency Distribution by Parity in Central Aceh Regency in 2020

\begin{tabular}{|c|c|c|}
\hline Parity & $\mathrm{n}$ & $\%$ \\
\hline 1. Risk & 54 & 45,0 \\
\hline 2. Not at risk & 66 & 55,0 \\
\hline Sum & 120 & 100 \\
\hline
\end{tabular}

Table 2. shows that of the 120 respondents studied, 54 respondents had risk parity ( 1 and $>4)$, and 66 respondents $(55 \%)$.

\section{Complications of Childbirth}

Table 3. Frequency Distribution According to Labor Complications in Central Aceh Regency in 2020

\begin{tabular}{|c|c|c|}
\hline Complications of Childbirth & $\mathrm{n}$ & $\%$ \\
\hline 1. Risk & 41 & 34,2 \\
2. Not at risk & 79 & 65,8 \\
\hline Sum & 120 & 100 \\
\hline
\end{tabular}

Table 3. shows that of the 120 respondents studied, 41 respondents $(34.2 \%)$ were at risk due to childbirth complications and 79 respondents $(65.8 \%)$.

\section{Birth Distance}

Table 4. Distribution of Frequency By Birth Distance in Central Aceh Regency in 2020

\begin{tabular}{|c|c|c|}
\hline Birth Distance & $\mathrm{n}$ & $\%$ \\
\hline 1. Risk & 54 & 45,0 \\
\hline 2. Not at risk & 66 & 55,0 \\
\hline Sum & 120 & 100 \\
\hline
\end{tabular}


Table 4. shows that of the 120 respondents studied, respondents at risk (distance from birth to last child $<2$ years) were 54 respondents $(45.0 \%)$, while respondents who were not at risk (birth distance 2 years) were 66 respondents $(55,0 \%)$.

\section{Nutritional Status}

Table 5. Distribution of Frequency by Nutritional Status in Central Aceh Regency in 2020

\begin{tabular}{|c|c|c|}
\hline LILA size & $\mathrm{n}$ & $\%$ \\
\hline 1. Risk & 20 & 16,7 \\
\hline 2. Not at risk & 100 & 83,3 \\
\hline Sum & 120 & 100 \\
\hline
\end{tabular}

Table 5. shows that of the 120 respondents studied, respondents who are not at risk (have good nutritional status as indicated by the size of the Upper Arm Circumference (LILA) $23.5 \mathrm{~cm}$ ) are 100 respondents $(83.3 \%$ ), while those who are at risk ( have poor nutritional status with the size of the upper arm circumference (LILA) $<23.5 \mathrm{~cm}$ ) as many as 10 respondents $(16.7 \%)$.

\section{Pregnancy Examination}

Table 6. Frequency Distribution according to Pregnancy Examination in Central Aceh Regency in 2020

\begin{tabular}{|l|c|c|}
\hline Pregnancy Examination & $\mathrm{n}$ & $\%$ \\
\hline 1. Risk & 48 & 40,0 \\
2. Not at risk & 72 & 60,0 \\
\hline Sum & 120 & 100 \\
\hline
\end{tabular}

Table 6. shows that of the 120 respondents studied, respondents who were at risk (conducted pregnancy checks $<4$ times and did not get complete services $10 \mathrm{~T})$ were 48 respondents $(40 \%)$ and those who were not at risk (conducted pregnancy tests $>4$ times and received medical services) complete $10 \mathrm{~T}$ ) which is 72 respondents $(60 \%)$.

\section{Delivery Helper}

Table 7. Distribution of Frequencies According to Childbirth Helpers in Central Aceh Regency in 2020

\begin{tabular}{|c|c|c|}
\hline Delivery Helper & $\mathrm{n}$ & $\%$ \\
\hline 1. Risk & 2 & 1,7 \\
2. Not at risk & 118 & 98,3 \\
\hline Sum & 120 & 100 \\
\hline
\end{tabular}

Table 7. shows that of the 120 respondents studied, respondents who were at risk (who chose traditional birth attendants as birth attendants) were 2 respondents (1.7\%) and those who were not at risk (selected obstetricians and midwives as birth attendants) were 118 respondents $(98,3 \%)$.

\section{Place of Delivery}

Table 8. Distribution of Frequency By Birth place in Central Aceh Regency in 2020

\begin{tabular}{|c|c|c|}
\hline Place of Delivery & $\mathrm{n}$ & $\%$ \\
\hline 1. Risk & 8 & 6,7 \\
\hline 2. Not at risk & 112 & 93,3 \\
\hline
\end{tabular}




\section{Sum}

120

100

Table 8. shows that of the 120 respondents studied, respondents who are at risk (choose to give birth at home) are 8 respondents (6.7\%) and those who are not at risk (choose Hospitals and Independent Practice Midwives as places of delivery) are 112 respondents $(93,3 \%)$.

\section{Bivariate Analysis}

\section{Relationship Between Maternal Age and Neonatal Death in Central Aceh Regency}

Table 9. Distribution of Maternal Age Relationship and Neonatal Death in Central Aceh Regency in 2020

\begin{tabular}{|c|c|c|c|c|c|c|c|}
\hline \multirow[t]{3}{*}{ Mother's Age } & \multicolumn{4}{|c|}{ Neonatal Death } & \multirow{2}{*}{\multicolumn{2}{|c|}{ Sum }} & \multirow{3}{*}{$p$} \\
\hline & \multicolumn{2}{|c|}{ Die } & \multicolumn{2}{|c|}{ Live } & & & \\
\hline & $\mathrm{f}$ & $\%$ & $f$ & $\%$ & $\mathrm{f}$ & $\%$ & \\
\hline 1. Risk & 27 & 67,5 & 13 & 32,5 & 40 & 100 & 0,012 \\
\hline 2. Not at risk & 33 & 41,3 & 47 & 58,8 & 80 & 100 & \\
\hline Sum & 60 & 50 & 60 & 50 & 120 & 100 & \\
\hline
\end{tabular}

In table 9. it is known that from 120 respondents aged $<20$ years or $>35$ years as many as 40 respondents, $27(67.5 \%)$ respondents experienced neonatal death and $13(32.5 \%)$ did not experience neonatal death. . While respondents aged 20-35 years were 80 respondents, with 33 $(41.3 \%)$ neonatal deaths and $47(58.8 \%)$ respondents who did not have neonatal deaths. The results of statistical tests obtained $p$ value $=0.012$, it can be concluded that there is a difference in the proportion of neonatal deaths between the ages of mothers who are at risk and those who are not at risk. Thus, it can be interpreted that there is a relationship between Maternal Age and Neonatal Mortality in Central Aceh District.

\section{Relationship Between Parity and Neonatal Deaths in Central Aceh Regency}

Table 10. Distribution of Parity Relationships and Neonatal Mortality in Aceh Tengah District in 2020

\begin{tabular}{|l|c|c|c|c|c|c|c|}
\hline \multirow{2}{*}{ Parity } & \multicolumn{4}{|c|}{ Neonatal Death } & \multicolumn{2}{c|}{ Sum } & \multirow{2}{*}{$P$} \\
\cline { 2 - 7 } & \multicolumn{2}{|c|}{ Die } & \multicolumn{2}{c|}{ Live } & \multicolumn{2}{|c|}{$P$} \\
\cline { 2 - 7 } & $\mathrm{f}$ & $\%$ & $\mathrm{f}$ & $\%$ & $\mathrm{f}$ & $\%$ & \\
\hline 1. Risk & 31 & 57,4 & 23 & 42,6 & 54 & 100 & 0,199 \\
2. Not at risk & 29 & 43,9 & 37 & 56,1 & 66 & 100 & \\
\hline Sum & 60 & 50 & 60 & 50 & 120 & 100 & \\
\hline
\end{tabular}

Table 10. From 120 respondents who had risky parity as many as 54 respondents, 31 (57.4\%) respondents experienced neonatal death and $23(42.6 \%)$. Meanwhile, respondents with nonrisk parity were 66 respondents, with $29(43.9 \%)$ neonatal mortality and $37(56.1 \%)$ respondents without neonatal mortality. The results of statistical tests obtained $p$ value $=0.199$, it can be concluded that there is no difference in the proportion of neonatal deaths between parity at risk and not at risk. Thus it can be interpreted that there is no relationship between Parity and Neonatal Mortality in Aceh Tengah District.

\section{Link Between Childbirth Complications and Neonatal Deaths in Central Aceh Regency}

Table 11. Distribution of Relationship of Neonatal Childbirth and Death Complications in Central Aceh Regency in 2020

\begin{tabular}{|l|l|l|l|}
\hline & Neonatal Death & Sum & \\
\hline
\end{tabular}

Copyright $@$ ( 2021, International Journal Papier Advance and Scientific Review, Under the license CC BY-SA 4.0

DOI: https://doi.org/10.47667/ijpasr.v2i2.123 


\begin{tabular}{|l|c|c|c|c|c|c|c|}
\hline \multicolumn{2}{|c|}{$\begin{array}{c}\text { Complications of } \\
\text { Childbirth }\end{array}$} & \multicolumn{2}{|c|}{ Die } & \multicolumn{2}{c|}{ Live } & & \multirow{2}{*}{$P$} \\
\cline { 2 - 8 } & f & $\%$ & f & $\%$ & F & $\%$ & \\
\hline 1. Risk & 25 & 61,0 & 16 & 39,0 & 41 & 100 & \\
2. Not at risk & 35 & 44,3 & 44 & 55,7 & 79 & 100 & \\
\cline { 1 - 8 } Sum & 60 & 50 & 60 & 50 & 120 & 100 & 0,124 \\
\hline
\end{tabular}

Table 11 shows that from 120 respondents who experienced childbirth complications as many as 41 respondents, $25(61 \%)$ respondents experienced neonatal death and $16(39 \%)$. While respondents who did not experience complications of childbirth were 79 respondents, with neonatal mortality as many as $35(44.3 \%)$ respondents and $44(55.7 \%)$ respondents who did not have neonatal death. The results of the statistical test obtained $\mathrm{p}$ value $=0.124$, it can be concluded that there is no difference in the proportion of neonatal deaths between those who experienced labor complications and those who did not experience childbirth complications. Thus, it can be interpreted that there is no relationship between Childbirth Complications and Neonatal Death in Aceh Tengah District.

\section{Relationship Between Birth Distance and Neonatal Death in Central Aceh Regency}

Table 12. Distribution of Neonatal Birth and Death Distance Relationship in Central Aceh Regency in 2020

\begin{tabular}{|c|c|c|c|c|c|c|c|}
\hline \multirow[t]{3}{*}{ Birth Distance } & \multicolumn{4}{|c|}{ Neonatal Death } & \multirow{2}{*}{\multicolumn{2}{|c|}{ Total }} & \multirow[t]{3}{*}{$P$} \\
\hline & \multicolumn{2}{|c|}{ Die } & \multicolumn{2}{|c|}{ Live } & & & \\
\hline & $\mathrm{f}$ & $\%$ & $f$ & $\%$ & $\mathrm{f}$ & $\%$ & \\
\hline 1. Risk & 31 & 57,4 & 23 & 42,6 & 54 & 100 & \\
\hline 2. Not at risk & 29 & 43,9 & 37 & 56,1 & 66 & 100 & \\
\hline Sum & 60 & 50 & 60 & 50 & 120 & 100 & 0,337 \\
\hline
\end{tabular}

Table 12. It is known from 120 respondents who had a risky birth spacing as many as 54 respondents, $31(57.4 \%)$ respondents experienced neonatal death and 23 (42.6\%). Meanwhile, respondents with non-risk parity were 66 respondents, with $29(43.9 \%)$ neonatal mortality and $37(56.1 \%)$ respondents without neonatal mortality. The results of statistical tests obtained $p$ value $=0.337$, so it can be concluded that there is no difference in the proportion of neonatal deaths between at-risk and non-risky births. Thus, it can be interpreted that there is no relationship between Birth Distance and Neonatal Death in Aceh Tengah District.

\section{Relationship Between Nutritional Status and Neonatal Deaths in Central Aceh Regency}

Table 13. Distribution of Relationship of Nutritional Status and Neonatal Death in Central Aceh Regency in 2020

\begin{tabular}{|l|c|c|c|c|c|c|c|c|}
\hline \multirow{2}{*}{} & LILA size & \multicolumn{4}{|c|}{ Neonatal Death } & \multicolumn{2}{c|}{ Sum } & \multirow{2}{*}{$p$} \\
\cline { 3 - 7 } & \multicolumn{2}{|c|}{ Die } & \multicolumn{2}{c|}{ Live } & \multicolumn{2}{c|}{} \\
\cline { 2 - 7 } & $\mathrm{F}$ & $\%$ & $\mathrm{f}$ & $\%$ & $\mathrm{f}$ & $\%$ & \\
\hline 1. & Risk & 10 & 50,0 & 10 & 50,0 & 20 & 100 & \\
2. & Not at risk & 50 & 50,0 & 50 & 50,0 & 100 & 100 & \\
\hline \multicolumn{2}{c}{ Sum } & 60 & 50 & 60 & 50 & 120 & 100 & 1,000 \\
\hline
\end{tabular}

Table 13. It is known from 120 respondents who had LILA size $<23 \mathrm{~cm}$ as many as 20 respondents, $10(50 \%)$ respondents experienced neonatal death and $10(50 \%)$ did not experience neonatal death. Meanwhile, 100 respondents with LILA size $23 \mathrm{~cm}, 50(50 \%)$ respondents with neonatal mortality and $50(50 \%)$ respondents without neonatal mortality. The 
results of statistical tests obtained $p$ value $=1,000$, it can be concluded that there is no difference in the proportion of neonatal deaths between nutritional statuses at risk and those without risk. Thus, it can be interpreted that there is no relationship between Nutritional Status and Neonatal Mortality in Aceh Tengah Regency.

\section{Relationship Between Pregnancy Examination and Neonatal Death in Central Aceh Regency}

Table 14. Distribution of Neonatal Pregnancy and Death Examination Relationship in Central Aceh Regency in 2020

\begin{tabular}{|c|c|c|c|c|c|c|c|}
\hline \multirow[t]{3}{*}{ ANC Frequency } & \multicolumn{4}{|c|}{ Neonatal Death } & \multirow{2}{*}{\multicolumn{2}{|c|}{ Sum }} & \multirow{3}{*}{$p$} \\
\hline & \multicolumn{2}{|c|}{ Die } & \multicolumn{2}{|c|}{ Live } & & & \\
\hline & $\mathrm{F}$ & $\%$ & $\mathrm{f}$ & $\%$ & f & $\%$ & \\
\hline 1. Risk & 29 & 60,4 & 19 & 39,6 & 48 & 100 & \\
\hline 2. Not at risk & 31 & 43,1 & 41 & 56,9 & 72 & 100 & 0,047 \\
\hline Sum & 60 & 50 & 60 & 50 & 120 & 100 & \\
\hline
\end{tabular}

Table 14. It is known that from 120 respondents who underwent pregnancy check-ups $<4$ times and did not receive complete $10 \mathrm{~T}$ services as many as 48 respondents, $29(60.4 \%)$ respondents experienced neonatal death and 19 (39.6) respondents did not experience neonatal death. \%). Meanwhile, 72 respondents who had prenatal care $>4$ times and received complete $10 \mathrm{~T}$ services, with $31(43.1 \%)$ neonatal deaths and 41 (56.9\%) respondents who did not have neonatal deaths. The results of statistical tests obtained $\mathrm{p}$ value $=0.047$, it can be concluded that there is a difference in the proportion of neonatal deaths between the frequency of antenatal examinations < 4 times and those 4 times. Thus, it can be interpreted that there is a relationship between Pregnancy Examination and Neonatal Death in Central Aceh District.

\section{Relationship Between Childbirth Helper and Neonatal Death in Central Aceh Regency}

Table 15. Distribution of Neonatal Childbirth and Death Assistance Relationship in Central Aceh Regency in 2020

\begin{tabular}{|l|c|c|c|c|c|c|c|}
\hline \multirow{2}{*}{ Delivery Helper } & \multicolumn{4}{|c|}{ Neonatal Death } & \multicolumn{2}{c|}{ Total } & \multirow{2}{*}{$p$} \\
\cline { 2 - 7 } & \multicolumn{2}{|c|}{ Die } & \multicolumn{2}{c|}{ Live } & \multicolumn{2}{c|}{} & \\
\cline { 2 - 8 } & $\mathrm{F}$ & $\%$ & $\mathrm{f}$ & $\%$ & $\mathrm{f}$ & $\%$ & \\
\hline 1. Risk & 1 & 50, & 1 & 50, & 2 & 100 & \\
2. Not at risk & 59 & 0 & 59 & 0 & 118 & 100 & \\
& & 50, & & 50, & & & 1,00 \\
& & 0 & & 0 & & & 0 \\
\hline \multicolumn{1}{|c|}{ Sum } & 60 & 50 & 60 & 50 & 120 & 100 & \\
\hline
\end{tabular}

Table 15. It is known that from 120 respondents who gave birth with non-health personnel there were 2 respondents, $1(50 \%)$ respondents experienced neonatal death and $1(50 \%)$ did not experience neonatal death. Meanwhile, 118 respondents who gave birth with health personnel, $59(50 \%)$ respondents with neonatal deaths and $59(50 \%)$ respondents who did not have neonatal deaths. The results of statistical tests obtained $\mathrm{p}$ value $=1,000$, it can be concluded that there is no difference in the proportion of neonatal deaths between birth attendants who are at risk and those who are not at risk. Thus, it can be interpreted that there is no relationship between Birth Attendants and Neonatal Deaths in Central Aceh District. 


\section{Relationship Between Childbirth and Neonatal Death in Central Aceh Regency}

Table 16. Distribution of Neonatal Childbirth and Death Relationships in Central Aceh Regency in 2020

\begin{tabular}{|c|c|c|c|c|c|c|c|}
\hline \multirow[t]{3}{*}{ Place of Delivery } & \multicolumn{4}{|c|}{ Neonatal Death } & \multirow{2}{*}{\multicolumn{2}{|c|}{ Sum }} & \multirow{3}{*}{$P$} \\
\hline & \multicolumn{2}{|c|}{ Die } & \multicolumn{2}{|c|}{ Live } & & & \\
\hline & $\mathrm{F}$ & $\%$ & $f$ & $\%$ & $\mathrm{~F}$ & $\%$ & \\
\hline 1. Risk & 4 & 50,0 & 4 & 50,0 & 8 & 100 & \\
\hline 2. Not at risk & 56 & 50,0 & 56 & 50,0 & 112 & 100 & \\
\hline Sum & 60 & 50 & 60 & 50 & 120 & 100 & 1,000 \\
\hline
\end{tabular}

Table 16 shows that from 120 respondents who gave birth at a non-health facility, 8 respondents experienced neonatal death, $4(50 \%)$ respondents and $4(50 \%)$ did not experience neonatal death. While respondents who gave birth with health workers were 112 respondents, $56(50 \%)$ respondents had neonatal deaths and $56(50 \%)$ respondents did not have neonatal deaths. The results of statistical tests obtained $p$ value $=1,000$, it can be concluded that there is no difference in the proportion of neonatal deaths between risky and non-risky places of delivery. Thus, it can be interpreted that there is no relationship between Place of Delivery and Neonatal Death in Central Aceh District.

\section{Multivariate Analysis}

Multivariate analysis was conducted to see which independent variables had the most influence on neonatal mortality. Logistic regression test was conducted to determine the most influential variable on neonatal mortality.

\section{Candidate Variable Selection}

In multivariate analysis, it begins with the selection of candidate variables, from the results of bivariate analysis which has a $\mathrm{p}$ value $<0.25$ will enter into multivariate analysis. Bivariate selection used a simple logistic regression test and the results were obtained as shown in the following table:

Table 17. Results of Bivariate Selection Analysis

\begin{tabular}{|c|l|c|}
\hline No & \multicolumn{1}{|c|}{ Variable } & P Value \\
\hline 1 & Mother's Age & 0,006 \\
2 & Parity & 0,141 \\
3 & Complications of Childbirth & 0,082 \\
4 & Birth Distance & 0,184 \\
5 & Nutritional Status & 1,000 \\
6 & Pregnancy Examination & 0,062 \\
7 & Delivery Helper & 1,000 \\
8 & Place of Delivery & 1,000 \\
\hline
\end{tabular}

In table 17 above, it can be seen that there are 5 (five) independent variables that have a p value $<0.25$, namely the variables of Maternal Age, Parity, Labor Complications, Birth Distance and Pregnancy Examination, then these variables will be entered into the multivariate stage. 


\section{Multivariate Modeling}

From the results of the candidate variable selection analysis, it was found that 5 (five) variables were included in the multivariate analysis because they had a $p$ value of $<0.25$, the variables were Maternal Age, Parity, Labor Complications, Birth Distance and Pregnancy Examination. Multivariate modeling analysis was carried out 2 (two) times modeling, as shown in the following table:

Table 18. Results of Multivariate Analysis of the Relationship of Maternal Age, Parity, Complications of Delivery, Birth Distance and Pregnancy Examination with Neonatal Mortality in Aceh Tengah District in 2020

\begin{tabular}{|c|c|c|c|c|c|c|c|c|c|}
\hline \multirow[b]{2}{*}{ Variable } & \multicolumn{4}{|c|}{ Model 1} & \multicolumn{4}{|c|}{ Model 2} & \multirow{2}{*}{$\begin{array}{l}\text { Model 3 } \\
\text { P Value }\end{array}$} \\
\hline & $\begin{array}{c}P \\
\text { Value }\end{array}$ & $\begin{array}{c}\text { OR } \\
\text { Parity } \\
\text { exists }\end{array}$ & $\begin{array}{c}\text { OR } \\
\text { Parity } \\
\text { does } \\
\text { not } \\
\text { exist. }\end{array}$ & $\begin{array}{c}\text { OR } \\
\text { Changes }\end{array}$ & $\begin{array}{c}P \\
\text { Value }\end{array}$ & $\begin{array}{c}\text { OR } \\
\text { Complic } \\
\text { ations of } \\
\text { Childbir } \\
\text { th exist }\end{array}$ & $\begin{array}{l}\text { OR } \\
\text { Complic } \\
\text { ations of } \\
\text { labor do } \\
\text { not exist }\end{array}$ & $\begin{array}{c}\text { OR } \\
\text { Changes }\end{array}$ & \\
\hline Mother's Age & 0,002 & 4,684 & 4,311 & $0,373 \%$ & 0,001 & 4,311 & 4,397 & $0,086 \%$ & 0,001 \\
\hline Parity & 0,626 & 0,762 & & & & & & & \\
\hline $\begin{array}{l}\text { Complications } \\
\text { of Childbirth }\end{array}$ & 0,263 & 1,611 & 1,605 & $0,006 \%$ & 0,267 & 1,605 & & & \\
\hline Birth Distance & 0,052 & 1,915 & 1,711 & $0,204 \%$ & 0,026 & 1,711 & 1,764 & $0,053 \%$ & 0,018 \\
\hline $\begin{array}{l}\text { Pregnancy } \\
\text { Examination }\end{array}$ & 0,036 & 2,466 & 2,451 & $0,015 \%$ & 0,037 & 2,451 & 2,700 & $0,3 \%$ & 0,018 \\
\hline
\end{tabular}

From table.18. shows the results of multivariate modeling analysis using multiple logistic regression and obtained 3 multiple logistic modeling models, the variable having a $p$ value > 0.05 must be excluded from the modeling.

\section{Maternal Age Relationship, Parity, Labor Complications, Birth Distance and Pregnancy Examination with Neonatal Death}

Multivariate analysis to see the most dominant factor associated with the incidence of neonatal death. The results of multivariate analysis if there is a variable that has a $p$ value $>0.05$ then that variable will be excluded from the multivariate analysis.

The results of the multivariate analysis using the logistic regression model 1 contained in table 16 it is known that there are 3 variables that have a $\mathrm{p}$ value $>0.05$, namely parity, labor complications and birth spacing, but in this case the parity variable is excluded first because the $\mathrm{p}$ value the biggest.

\section{Maternal Age Relationship, Labor Complications, Birth Distance and Pregnancy Examination with Neonatal Death}

Model 2 in table 16 obtained from the results of multivariate analysis using logistic regression test after removing the parity variable, from modeling the variable that has a $p$ value $>0.05$ is the labor complication variable. The next variable that was excluded from the analysis was the variable of labor complications. 


\section{Maternal Age Relationship, Birth Distance and Pregnancy Examination with Neonatal Death}

From the results of multivariate analysis with multiple logistic regression test, it is known that there is no independent variable that has a $\mathrm{p}$ value $>0.05$, so it can be seen that there are 3 variables that have a relationship with the incidence of neonatal death, the variables are maternal age, birth spacing and examination pregnancy. From the results of the analysis, it is known that the variable of maternal age is the most dominant variable associated with the incidence of neonatal death because it has an OR value of 4.397.

\section{Maternal Age Relationship with Neonatal Death}

Based on the analysis using the chi square test, the $\mathrm{p}$ value is 0.006 , meaning that at $5 \%$ alpha there is a relationship between maternal age and neonatal mortality in Central Aceh District. The age of the mother at the time of pregnancy and the age of the mother at the time of the next pregnancy affect the health condition of the mother, various research results have been put forward related to age as a risk factor for the occurrence of early neonatal death. The age of a woman who is pregnant or giving birth does not directly cause neonatal death, but age is a risk factor because it can indirectly make a mother experience a condition that can pose a risk to the baby to be born.

Planning a pregnancy at a safe age is the most appropriate choice to reduce the risk of experiencing neonatal death. Pregnancy at a young age puts the mother at risk for anemia, impaired fetal growth and development, miscarriage, premature and low birth weight labor and delivery disorders. The risk experienced by the mother of course has a direct effect on the condition of the baby being born, whether it is LBW, premature and also asphyxia, this risk is a risk factor for a baby to experience neonatal death. While pregnancy at the age of more than 35 years also has the same risk as if pregnant at the age of less than 20 years, besides being able to cause pregnancy abortion at this age, it also increases the occurrence of chromosomal abnormalities that occur due to decreased egg quality.

\section{The Relationship of Parity with Neonatal Mortality}

Parity is the number of children born to a mother, both live and stillborn. A mother who gives birth frequently has a risk of experiencing neonatal death.

Babies born to mothers with parity $>4$ have a higher risk of infant mortality. This is because mothers with 4 pregnancies or more are more likely to experience weak contractions at the time of delivery, bleeding after delivery, placenta previa, preeclampsia, transverse labor, and prolonged labor. The higher the parity, the higher the risk of perinatal death because at the time of delivery the blood vessels in the damaged uterine wall cannot fully recover as before delivery. Therefore, repeated pregnancy and childbirth causes damage to the blood vessels in the uterine wall. And more and more will affect the circulation of food to the fetus and can cause disturbances and obstacles to fetal growth in the womb, abortion, congenital defects, low birth weight and neonatal death.

The relationship between parity and neonatal mortality showed a similar pattern to the age factor. Several studies conducted in Norway, America, found a tendency for neonatal mortality to increase by 7.3 times in mothers with a history of previous births experiencing 2 deaths in the neonatal period, while mothers with a history of neonatal death in their first birth were likely to experience neonatal death in subsequent births. 4.5 times, it is stated that parity $>3$ 
indicates the proportion of neonatal mortality is $41.08 \%$. It is also said that the birth of children $>5$ is a risk factor for experiencing neonatal death (Mugeni, 2010).

\section{Relationship of Childbirth Complications with Neonatal Death}

The results of the chi square test obtained a p value of 0.124 , meaning that at $5 \%$ alpha there was no significant relationship between the occurrence of childbirth complications between those who experienced neonatal death and those who did not.

Complications of delivery are very influential with neonatal mortality. The need for health services for a woman will increase and reach its peak during pregnancy and before delivery. The relationship between the fate of mother and baby which describes a unity that begins during pregnancy, childbirth, until the beginning of the first life, the baby really needs considerable attention, the incidence of obstetric complications is found in about $20 \%$ of all pregnancies, but which is handled is still less than $10 \%$. Three delays that affect neonatal mortality are being late in recognizing danger and making a decision to refer, being late in reaching a referral facility and being late in obtaining an adequate referral facility.

\section{Relationship between birth spacing and neonatal mortality}

The results of the chi square test obtained a $p$ value of 0.337 , meaning that at $5 \%$ alpha there was no significant relationship between the number of children born between those who experienced neonatal death and those who did not experience neonatal death. Meanwhile, for the birth spacing of more than 4 years, some mothers said it was due to economic reasons. who have improved as well as efforts to have children of a certain gender. Efforts that can be made to reduce the risk are by adjusting the birth spacing, planning pregnancy at a safe distance so as not to be at a risky distance.

\section{Relationship between Nutritional Status and Neonatal Mortality}

The results of the chi square test obtained a $\mathrm{p}$ value of 1,000 , meaning that at $5 \%$ alpha there was no significant relationship between nutritional status between those who experienced neonatal death and those who did not experience neonatal death.

The nutritional status of pregnant women is a very important indicator to determine the nutritional status of the community because it is at this momentum that the quality of future generations is formed. Diet and nutritional status in pregnant women determine whether a mother can pass her pregnancy well without any disturbances. A healthy diet for pregnant women must meet the needs of pregnant women. An unhealthy diet can make the nutrients received are not sufficient for pregnant women and cause several impacts on pregnant women including preeclampsia, prematurity, osteomalacia, Chronic Energy Deficiency (KEK) and anemia.

\section{Pregnancy Examination Relationship with Neonatal Death}

The results of the chi square test obtained a p value of 0.047 , meaning that at $5 \%$ alpha there is a significant relationship between pregnancy tests and those who do not experience neonatal death.

This study is in line with research conducted by Ima Azizah, et al. (2017) which states that there is a relationship between antenatal care and neonatal mortality.

Antenatal Care (ANC) examination is carried out to determine the condition of the mother or fetus in her womb, so that it can perform early detection if complications or problems occur during pregnancy, childbirth or the puerperium (Oktarina, 2017). 


\section{The Relationship of Birth Attendants to Neonatal Death}

The results of the chi square test obtained a $\mathrm{p}$ value of 1,000 , meaning that at $5 \%$ alpha there was no significant relationship between birth attendants who experienced neonatal deaths and those who did not experience neonatal deaths. Proper and adequate medical treatment during childbirth can reduce the risk of complications that can cause serious pain to the mother. Mothers who give birth with the help of non-health workers have a tendency to experience infant mortality by 2.01 times greater than mothers who give birth to babies with the help of health workers (Faisal, 2010).

\section{Relationship of Childbirth to Neonatal Death}

The results of the chi square test obtained a $\mathrm{p}$ value of 1,000 , meaning that at $5 \%$ alpha there was no significant relationship between place of delivery between those who experienced neonatal death and those who did not experience neonatal death.

Neonatal deaths mostly occur in births that are not carried out at health facilities and are not carried out by trained health workers (delivery assistants). Only one third of births in developing countries occur in health facilities. While the delivery process is assisted by trained health personnel only about 50\% of all pregnant women (Lawn, McCarthy, \& Ross, 2001).

\section{Relationship between Maternal Age, Birth Spacing and Pregnancy Check-ups with Neonatal Mortality}

The results of this multiple multivariate analysis after 2 times of modeling it is known that there is no independent variable that has a $p$ value $>0.05$, so it can be seen that there are 3 variables that have a relationship with the incidence of neonatal death, the variables are maternal age, birth spacing and pregnancy examinations. . From the results of the analysis, it is known that the variable of maternal age is the most dominant variable associated with the incidence of neonatal death because it has an OR value of 4.397.

\section{Conclusion}

Based on the conclusions obtained from this study, several suggestions can be made that can be applied and used to improve early neonatal health status, namely increasing education to the public about risk factors, causes of infant mortality and efforts to prevent infant mortality to mothers and prospective mothers and their families. to pay attention to pregnant women considering that there are still some women who work while pregnant who show a lack of environmental attention to pregnant women. Socializing to pregnant women about the use of the $\mathrm{MCH}$ handbook as a tool for early detection of risky pregnancies so as to prevent neonatal deaths. For midwives on duty in the village to be able to carry out early detection activities for pregnant women at risk in an effort to capture risky cases during childbirth.

\section{References}

Ditami, N.A, (2016), Faktor Kejadian Kematian Bayi Di Kabupaten Gowa Tahun 2016,http://digilib.unhas.ac.id/uploaded_files/temporary/DigitalCollection/ZjZhYm Q3Zjg1YWMzM2U3NWQ1NzN1ZjRiMTY0MTQxMGEzNmUzZjE5Yg==.pdf

Latifah, N. (2012). Hubungan Frekuensi Kunjungan ANC Selama Kehamilan dengan Kejadian Kematian Neonatal. FKM Universitas Indonesia.

Oktarina, M. (2015). Buku ajar asuhan kebidanan persalinan dan bayi baru lahir. Deepublish. 
Prabamurti, P. N., Purnami, C. T., Widagdo, L., \& Setyono, S. (2008). Analisis Faktor Risiko Status Kematian Neonatal Studi Kasus Kontrol di Kecamatan Losari Kabupaten Brebes Tahun 2006. Jurnal Promosi Kesehatan Indonesia, 3(1), 1-9.

Susanti, N. (2016). Faktor-Faktor yang Berhubungan dengan Kejadian Kematian Neonatal (Studi Kasus di Kabupaten Grobogan Tahun 2014) (Doctoral dissertation, Universitas Negeri Semarang).

Yani, D. F., \& Duarsa, A. B. S. (2013). Pelayanan kesehatan ibu dan kematian neonatal. Kesmas: Jurnal Kesehatan Masyarakat Nasional (National Public Health Journal), 7(8), 373-377. 